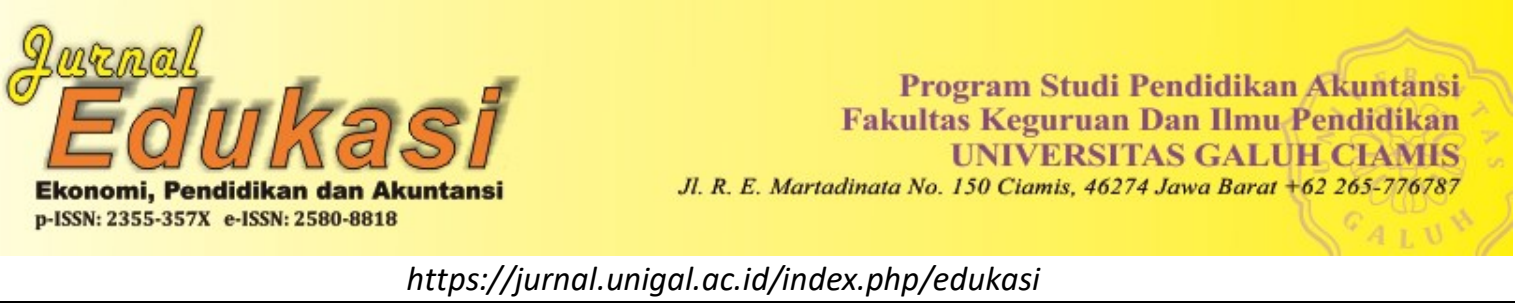

\title{
EVALUASI KINERJA KEUANGAN BANK PEMBANGUNAN DAERAH DI INDONESIA
}

\author{
Oleh: \\ Risna Kartika ${ }^{1}$, Faizal Haris Eko Prabowo², Dendy Syaiful Akbar ${ }^{3}$ \\ ${ }^{1,2,3}$ Fakultas Ekonomi, Universitas Galuh \\ Jalan RE Martadinata No 150, Ciamis \\ ${ }^{1}$ risnakartika@gmail.com \\ Sejarah Artikel: Diterima Maret 2020, Disetujui April 2020, Dipublikasikan Juni 2020
}

\begin{abstract}
ABSTRAK
Permasalahan dalam penelitian ini ialah tingkat kredit macet yang tergolong tinggi pada BPD pada tahun 2019 yaitu sebesar 12,175\%. Penelitian ini bertujuan mengetahui kinerja keuangan BPD di Indonesia menggunakan Capital Adequacy Ratio, Return On Asset dan Loan To Deposit Ratio. Metode yang digunakan ialah metode dekskriptif. Hasil penelitian menunjukkan bahwa BPD di Indonesia pada tahun 2019 memiliki rata-rata CAR sebesar $21,7 \%$ jauh diatas CAR minimal yang ditetapkan oleh Bank Indonesia sebesar 8\%, serta memiliki rata-rata ROA sebesar 2,16\% yang juga lebih besar dari minimal ROA sebesar $1,5 \%$, selanjutnya untuk rata-rata LDR Bank Pembangunan Daerah sebesar $80,43 \%$ yang berada pada range standard LDR, sehingga dapat dikatakan BPD di Indonesia termasuk dalam ketrgori likuid. Maka berdasarkan hasil penelitian yang dilakukan dapat disimpulkan bahwa kinerja keuangan Bank Pembangunan Daerah di Indonesia selama periode Januari 2019 sampai dengan Desember 2019 adalah baik.
\end{abstract}

Kata Kunci: kinerja keuangan, BPD, capital adequacy ratio, return on asset, loan to deposit ratio

\section{ABSTRACT}

The problem in this research is the high level of NPL in BPD that is equal to12,175\%. This study aims to determine the financial performance of BPD in Indonesia using the Capital Adequacy Ratio, Return On Assets and Loan To Deposit Ratio. The method used is descriptive method. The results showed that BPD in Indonesia in 2019 had an average CAR of $21.7 \%$ far above the minimum CAR set by Bank Indonesia of $8 \%$, and had an average ROA of $2.16 \%$ which was also greater than the minimum ROA of $1.5 \%$, then for the averag LDR of $80.43 \%$ which is in the LDR standard range, so it can be said that BPD in Indonesia is included in the category of liquid. So based on the results it can be concluded that the financial performance of BPD in Indonesia during the period January 2019 to December 2019 is good.

Keywords: financial performance, BPD, capital adequacy ratio, return on asset, loan to deposit ratio

\section{PENDAHULUAN}

Bank merupakan lembaga keuangan yang turut serta dalam menopang perokonomian Indonesia. Fungsinya sendiri yaitu sebagai lembaga intermediasi memiliki peran yang amat penting bagi masyarakat atau dengan kata lain bank ialah lembaga yang memfasilitasi atau mempertemukan antara pihak yang kekurangan dana dengan pihak yang kelebihan dana (Fiscal \& Lusiana, 2014; Mamahit \& Sumiyarsih, 2018; Rahmani, 2017; Ramadaniar, Topowijono, \& Husaini, 2013; Setiawan, 2017). Terdapat dua kegiatan utama bank, yaitu melakukan penghimpunan dana dari masyarakat dalam bentuk simpanan baik simpanan tabungan, deposito ataupun giro dan 
menyalurkannya kembali ke masyarakat dalam bentuk pinjaman, hal ini bertujuan untuk meningkatkan kesejahteraan masyarakat (Y. M. W. Putri \& Akmalia, 2016).

Di Indonesia sendiri, terdapat dua jenis bank yaitu Bank Umum dan Bank Perkreditan Rakyat atau BPR, perbedaanya terdapat beberapa kegiatan yang memang dilarang bagi BPR (Fiscal \& Lusiana, 2014), diantaranya melaksanakan kegiatan usaha dalam valuta asing dan melakukan usaha perasuransian. Secara umum persaingan perbankan di Indonesia dapat dikategorikan cukup tinggi berkaitan dengan jumlah bank yang sangat banyak, yaitu 110 Bank Umum dengan 31.077 kantor (SPI OJK, 2019). Bank umum sendiri menurut kepemilikannya terbagi dalam 5 jenis, yaitu Bank Milik Pemerintah Pusat, Bank Milik Pemerintah Daerah, Bank Milik Swasta Asing Nasional dan Bank Campuran. Sampai dengan Desember 2019 Bank Milik Pemerintah Daerah atau Bank Pembangunan Daerah di Indonesia tercatat sebanyak 26 Bank, dilihat dari sisi asset pada Bank Umum, BPD memiliki peringkat ke empat setelah Bank persero, BUSN Devisa dan BUSN Non Devisa, sampai dengan Desember 2019 total asset BPD di Indonesia sebesar Rp. 717.518 Milyar (SPI OJK, 2019).

Sesuai dengan fungsinya menyalurkan dana kepada masyarakat dalam bentuk pinjaman berupa kredit dengan tujuan membantu meningkatkan kesejahteraan masyarakat (Mamahit \& Sumiyarsih, 2018; Paramita \& Dana, 2019; Sulistiyorini, 2020). Kredit yang disalurkan oleh pihak perbankan dapat bersifat produktif maupun konsumtif, kredit produktif ialah kredit yang digunakan untuk keperluan usaha, contohnya ialah kredit modal kerja. Sedangkan kredit konsumtif dapat berupa kredit kepemilikan rumah, kredit kepemilikan kendaraan ataupun kredit serbaguna seperti kartu kredit (Aprilianawati, Zahroh, \& Nuzula, 2014; Mandolang, Kumaat, \& Niode, 2017). Kredit yang disalurkan sampai dengan Desember 2019 oleh BPD pada masyarakat didominasi oleh kredit konsumsi sebanyak Rp. 321.681 Milyar, kedua ialah kredit modal kerja sebesar Rp. 89.698 Milyar dan yang terakhir ialah kredit investasi sebesar Rp. 53.056 Milyar, permasalahan yang timbul ialah NPL yang termasuk dalam ketegori tinggi yaitu sebesar $12,175 \%$ pada Desember 2019, bahkan pada Mei 2019 tercatat NPL tertinggi sepanjang tahun 2019 yaitu sebesar 13,785\% (SPI OJK, 2020). Dikaitkan dengan kebijakan dari Bank Indonesia, NPL maksimum perbankan ialah 5\%, sehinggal NPL BPD di Indonesia pada Desember 2019 melampaui NPL maksimum yang ditetapkan Bank Indonesia.

Dengan demikian perlu adanya penilaian kinerja keuangan untuk Bank BPD untuk mengetahui tingkat kesehatan bank. Kinerja adalah sesuatu yang menunjukkan sejauh mana perusahaan dapat dengan efisien dan efektif mengalokaiskan sumberdayanya (Rahmani, 2017) Kinerja keuangan merupakan analisis dan gambaran hasil, untuk mengetahui sejauh mana kemampuan perusahaan dalam menjalankan aktivitas usahanya sesuai peraturan yang ada yang kemudian disajikan dalam laporan keuangan (Assofia, 2019; Ramadaniar et al., 2013). Kinerja keuangan suatu bank dapat tercermin dari laporan keuangannya (Rahmani, 2017), sehingga salah satu cara untuk menilai kinerja keuangan ialah dengan menghitung rasio keuangan (Ramadaniar et al., 2013). Rasio keuangan ialah perbandingan antara angkaangka pada laporan keuangan yang memberikan arti. Rasio keuangan sangat penting guna menganalisis kondisi perusahaan, sehingga erta kaitannya dengan penialain kinerja keuangan (Rate, Mangantar, \& Mamahit, 2016). Terdapat berbagai jenis rasio keuangan, diantaranya ialah rasio profitabilitas untuk mengukur kemampuan perusahaan dalam menghasilkan keuntungan, rasio solvabilitas ialah rasio untuk mengukur kemampuan perusahaan dalam memenuhi kewajiban jangka panjang dan rasio likuiditas ialah kemampuan perusahaan dalam memenuhi kewajiban jangka pendeknya (Septiyani, Mutmainah, \& Yulia, 2018). Rasio Solvabilitas yang digunakan ialah Capital Adequacy Ratio (CAR) yaitu rasio kecukupan modal guna menunjang aset yang beresiko (Y. M. W. Putri \& Akmalia, 2016; Setiyono \& Aini, 2014), selanjutnya rasio profitabilitas yang digunakan ialah Return On Asset (ROA) yaitu rasio untuk mengetahui dan mengukur kemampuan perusahaan menghasilkan profit berdasarkan aset tertentu (Mamahit \& Sumiyarsih, 2018; Y. M. W. Putri \& Akmalia, 2016) dan yang terakhir yaitu rasio likuiditas yang digunakan ialah Loan To Deposit Ratio (LDR) yaitu rasio kredit yang diberikan terhadap dana yang diterima atau sejauh mana simpanan diberikan atau digunakan untuk pinjaman (kredit) (Y. M. W. Putri \& Akmalia, 2016; Setiyono \& Aini, 2014; Sulistiyorini, 2020). 
Berikut penelitian terdahulu mengenai kinerja keuangan pada Bank Pembangunan Daerah di Indonesia. Penelitian selanjutnya meneliti mengenai faktor-faktor yang mempengaruhi kinerja keuangan pada perusahaan asuransi di Indonesia (Sumartono \& Harianto, 2018). Analisis kinerja keuangan pada Bank Aceh yang mengacu pada POJKNomor 8 tahun 2018 (Assofia, 2019). Penelitian lain menunjukkan bahwa kierja keuangan yang dihitung dengan dengan rasio solvabilitas, rentabilitas dan likuiditas pada Bank Mandiri memiliki kinerja keuangan yang baik (Ramadaniar et al., 2013). Penelitian lain menunjukkan bahwa tidak terdapat perbedaan yang signifikan kinerja keuangan bank milik pemerintah dengan bank milik swasta nasional berdasarkan rasio CAR, ROA, LDR, BOPO, dan NPL, berbeda secara signifikan hanya pada rasio ROE (Rate et al., 2016). Penelitian selanjutnya mengkaji mengenai factor-faktor yang mempengaruhi rasio profitabilitas dengan menggunakan ROA pada perbankan syariah di Indonesia (Sudarsono, 2017). Selanjutnya penelitian lain menganalisis pengaruh kinerja keuangan BPD dan BPR pada Pemberian Kredit (Wowiling, 2018). Penelitian lain menganalisis mengenai kinerja keuangan Bank BPR dengan metode CAMEL menunjukkan bahwa Bank BPR Delta Purnama termasuk dalam kategori bank yang sehat karena memperoleh nilai kredit CAMEL lebih dari 81 (Setiyono \& Aini, 2014). Penelitian lain mengkaji mengenai rasio keuangan (CAR, NPL, ROA dan LDR) terhadap penyalura kredit pada perbankan (Y. M. W. Putri \& Akmalia, 2016). Selanjutnya, penelitian lain dilakukan untuk mengetahui pengaruh tingkat kesehatan bank terhadap ROA dengan menggunakan Risk Based Bank Rating Method (Setiawan, 2017), penelitian berbeda dilakukan untuk mengetahui kinerja keuangan Bank umum Syariah dan Bank Konvensional di Indonesia yang dipengaruhi oleh tingkat kesehatan bank (M, Ali, \& Habbe, 2012). Penelitian lain bertujuan mengetahui factor-faktor yang mempengaruhi kinerja keuangan di perusahaan asuransi (Sumartono \& Harianto, 2018). Perbedaanya, penelitian ini menggunakan variable kinerja keuangan rasio profitabilitas yaitu retun On Asset (ROA), rasio solvabilitas yaitu Capital Adequacy ratio (CAR) dan rasio likuiditas yaitu Loan to Deposit Ratio (LDR) pada Bank Pembangunan Daerah di Indonesia, dengan tujuan dari penelitian ini ialah untuk mengetahui kinerja keuangan Bank Pembangunan Daerah (BPD) di Indonesia.

\section{METODE PENELITIAN}

Penelitian ini menggunakan metode penelitian deskriptif dengan pendekatan literature review. Literature review merupakan suatu metode yang mendeskripsikan suatu temuan atau teori yang diperoleh dari berbagai sumber yang kemudian digunakan sebagai dasar atau referensu untuk menyelesaikan masalah (Prawirasasra, 2018).

Jenis data yang digunakan dalam penelitian ini ialah data sekunder berupa rasio keuangan Capital Adequacy Ratio, Loan to Deposit Ratio dan Return On Asset rata-rata Bank Pembangunan Daerah yang berjumlah 26 BPD dari Januari 2019 sampai dengan Desember 2019, yang bersumber dari Statistik Perbankan Indonesia Otoritas Jasa Keuangan.

\section{HASIL PENELITIAN DAN PEMBAHASAN \\ Capital Adequacy Ratio (CAR)}

Capital Adequacy Ratio atau biasa disingkat dengan CAR ialah rasio kecukupan modal bank. CAR menjadi Salah satu indikator penting bagi perbankan karena berkaitan dengan kewajiban bank yang harus dipenuhi dari sisi modal yang menjadi gambaran dalam bentuk modal minimum (I. G. A. P. Putri \& Suryantini, 2017). Nilai CAR dapat diperoleh dengan perbandingan antara modal bank dengan Aktiva Tertimbang menurut Risiko atau ATMR (Rate et al., 2016). Sesuai dengan ketentuan yang dikeluarkan oleh Bank Indonesia minimal SE BI No.13/24/DPNP/2011 CAR yang harus dipernuhi oleh bank ialah sebesar $8 \%$, jika bank memiliki CAR lebih dari $8 \%$ artinya bank tersebut masuk dalam kategori baik dan aman karena memiliki tingkat kecukupan modal yang baik. Kecukupan modal sangat penting bagi bank karena modal yang cukup atau dikatgeorikan banyak akan digunakan untuk memperlancar kegiatan usaha atau operasional perusahaan (Fiscal \& Lusiana, 2014). Berikut merupakan data rata-rata modal bank, Aktiva Tertimbang menurut Risiko (ATMR) dan CAR pada Bank Pembangunan Daerah di Indonesia selama periode Januari 2019 sampai dengan Desember 2019 yang tersaji pada Tabel 1. 
Tabel 1:

Rata-rata Modal Bank, ATMR dan CAR BPD periode Januari sd Desember 2019

\begin{tabular}{cccccccc}
\hline Bulan & $\begin{array}{c}\text { Modal } \\
\text { (Milyar Rupiah) }\end{array}$ & $\begin{array}{c}\text { ATMR } \\
\text { (Milyar Rupiah) }\end{array}$ & CAR & Bulan & $\begin{array}{c}\text { Modal } \\
\text { (Milyar Rupiah) }\end{array}$ & $\begin{array}{c}\text { ATMR } \\
\text { (Milyar Rupiah) }\end{array}$ & CAR \\
\hline Januari & 78.545 & 352.209 & $22,30 \%$ & Juli & 75.532 & 349.111 & $21,64 \%$ \\
Februari & 79.723 & 354.608 & $22,48 \%$ & Agustus & 76.161 & 370.809 & $20,54 \%$ \\
Maret & 78.500 & 357.942 & $21,93 \%$ & September & 77.276 & 380.318 & $20,32 \%$ \\
April & 76.463 & 357.170 & $21,41 \%$ & Oktober & 78.515 & 384.164 & $20,44 \%$ \\
Mei & 73.884 & 358.305 & $20,62 \%$ & November & 79.944 & 387.700 & $20,62 \%$ \\
Juni & 74.770 & 364.123 & $20,53 \%$ & Desember & 81.327 & 383.759 & $21,19 \%$ \\
\hline \multicolumn{7}{c}{ Sumber: SPI OJK, 2019.} \\
\end{tabular}

Berdasarkan data yang terdapat pada Tabel 1. Menunjukkan bahwa CAR Bank Pembangunan Daerah periode Januari 2019 sampai dengan Desember 2019 tergolong cukup fluktuatif, tetapi masih pada range yang sangat baik yaitu diatas $20 \%$ atau dengan rata-rata $21,17 \%$. Jika dilihat dari sisi permodalan rata-rata CAR $21,17 \%$ dapat diperingkatkan bersadarkan peraturan Surat Edaran No.13/24/DPNP tanggal 25 Oktober 2011 yang terdapat pada tabel 2.

Tabel 2:

Nilai untuk Peringkat ROA dan CAR

\begin{tabular}{cccl}
\hline & \multicolumn{2}{c}{ ROA } & \multicolumn{2}{c}{ CAR } \\
\hline Peringkat & Nilai & Peringkat & \multicolumn{1}{c}{ Nilai } \\
\hline 1 & $\mathrm{ROA}>1,5 \%$ & 1 & $\mathrm{CAR} \geq 12 \%$ \\
2 & $1,25 \%<\mathrm{ROA} \leq 1,5 \%$ & 2 & $9 \% \leq \mathrm{CAR}<12 \%$ \\
3 & $0,5 \%<\mathrm{ROA} \leq 1,25 \%$ & 3 & $8 \% \leq \mathrm{CAR}<9 \%$ \\
4 & $0 \%<\mathrm{ROA} \leq 0,5 \%$ & 4 & $46 \%<\mathrm{CAR}<8 \%$ \\
5 & $\mathrm{ROA} \leq 0 \%$ & 5 & $\mathrm{CAR} \leq 6 \%$ \\
\hline
\end{tabular}

Sumber: SE BI No.13 / 24 / DPNP / 2011

Dilihat dari Tabel 2. dari sisi permodalan CAR Bank Pembangunan Daerah di Indonesia berada pada peringkat pertama, yaitu $\mathrm{CAR} \geq 12 \%$, peringkat pertama mencerminkan kondisi yang paling baik. Bank yang memiliki CAR lebih dari 8\% menunjukkan bahwa bank memiliki usaha yang stabil (Paramita \& Dana, 2019). CAR yang besar didukung oleh modal yang tinggi yang dimiliki oleh Bank Pembangunan Daerah. CAR merupakan rasio yang berperan untuk menampung risiko yang mungkin terjadi pada pihak bank, semakin besar atau tinggi nilai CAR suatu perbankan artinya semakin baik pula kemampuan bank dalam menghadapi risiko dari setiap kredit atau ATMR (aktiva tertimbang menurut risiko (Rahmani, 2017). Aktiva tertimbang menurut risiko sepanjang tahun 2019 pada Bank Pembangunan Daerah setiap bulannya mengalami fluktuatif yang cenderung meningkat, hal ini dimbangi oleh jumlah modal bank yang juga cenderung meningkat. CAR Bank Pembangunan Daerah di Indonesia ini dapat dikategorikan besar dapat memberikan rasa aman dan nyaman kepada konsumen atau nasabah untuk melakukan transaksi perbankan di Bank pembanguna Daerah di Indonesia, karena CAR dengan nilai rata-rata 21,17\% menggambarkan kondisi kesehatan bank yang sangat baik dan menunjukkan kepercayaan masyarakat terhadap bank tersebut tinggi (Paramita \& Dana, 2019; Y. M. W. Putri \& Akmalia, 2016; Rahmani, 2017; Setiyono \& Aini, 2014), sebaliknya nilai CAR yang rendah mencerminkan permodalan bank yang semakin lemah (Fiscal \& Lusiana, 2014).

\section{Return on Asset (ROA)}

Return on Asset (ROA) ialah bagian dari rasio profitabilitas atau rentabilitas yang dilihat dari perbandingan antara earning before tax (EBT) dengan total aktiva yang dimiliki oleh bank, rasio ini juga menunjukkan tingkat efisiensi manajemen dalam memperoleh keuntungan dilihat dari segi aset (Ayem \& Wahyuni, 2017; Mamahit \& Sumiyarsih, 2018; Ramadaniar et al., 2013). Berikut merupakan data rata-rata laba sebelum pajak atau earning before tax (EBT), keseluruhan total aktiva BPD dan ROA pada Bank Pembangunan Daerah di Indonesia selama periode Januari 2019 sampai dengan Desember 2019 yang tersaji pada Tabel 3. 
Tabel 3:

Rata-rata EBT, Total Aset dan ROA periode Januari sd Desember 2019

\begin{tabular}{cccccccc}
\hline Bulan & $\begin{array}{c}\text { EBT } \\
\text { (Milyar Rupiah) }\end{array}$ & $\begin{array}{c}\text { Total Asset } \\
\text { (Milyar Rupiah) }\end{array}$ & ROA & Bulan & $\begin{array}{c}\text { EBT } \\
\text { (Milyar Rupiah) }\end{array}$ & $\begin{array}{c}\text { Total Asset } \\
\text { (Milyar Rupiah) }\end{array}$ & ROA \\
\hline Januari & 14.188 & 615.176 & $2,31 \%$ & Juli & 13.585 & 644.829 & $2,11 \%$ \\
Februari & 14.656 & 619.764 & $2,36 \%$ & Agustus & 13.632 & 647.716 & $2,10 \%$ \\
Maret & 14.117 & 626.121 & $2,25 \%$ & September & 14.019 & 652.008 & $2,15 \%$ \\
April & 12.906 & 634.972 & $2,03 \%$ & Oktober & 14.244 & 657.750 & $2,17 \%$ \\
Mei & 13.213 & 635.451 & $2,08 \%$ & November & 14.183 & 662.128 & $2,14 \%$ \\
Juni & 13.527 & 640.776 & $2,11 \%$ & Desember & 14.267 & 663.919 & $2,15 \%$ \\
\hline
\end{tabular}

Sumber: SPI OJK, 2019.

ROA Bank Pembangunan Daerah di Indonesia sepanjang tahun 2019 cenderung stabil dan selalu lebih dari 2\%, aset Bank Pembangunan Daerah cenderung meningkat di tahun 2019 dengan rata-rata Rp. 641.718 Miliar, dengan rata-rata laba sebelum pajak yang diperoleh sebesar Rp. 13. 878 Miliar. Rata-rata ROA setiap bulannya ialah sebesar 2,16\% artinya Bank Pembangunan Daerah memiliki ROA yang lebih besar dari $1,5 \%$ sehingga dapat dikategorikan baik, marujuk pada SE BI No.13 / 24 / DPNP / 2011 yang tersaji pada Tabel 2. Meskipun terjadi fluktuasi laba dari awal tahun sampai dengan pertengahan tahun, tetapi dari bulan Juni 2019 sampai dengan Desember 2019 laba sebelum pajak Bank Pembangunan Daerah di Indonesia terus mengalami kenaiakan, sedikit berbeda dengan jumlah asetnya yang terus mengalami kenaikan. Ini menunjukkan kemampuan Bank Pembangunan Daerah di Indonesia dari segi profitabilitas yang diwakili oleh ROA ialah sangat baik, karena ROA adalah salah satu indikator kinerja keuangan yang sangat penting yang mencerminkan kinerja bank dalam mengukur efektifitas perusahaan dalam memperoleh laba atau profit dengan menggunakan aset yang dimilikinya secara optimal (Chandra, 2013; Fiscal \& Lusiana, 2014; Rahmani, 2017). Semakin tinggi nilai ROA maka menggambarkan kemampuan perusahaan dalam menghasilkan laba semakin baik, sehingga dapat dikatakan kinerja keuangan perusahaan atau bank yang bersangkutan adalah baik (Paramita \& Dana, 2019).

\section{Loan to Deposit Ratio (LDR)}

Loan to Deposit Ratio (LDR) adalah perimbangan antara jumlah kredit yang diberikan dengan total DPK atau dana pihak ketiga, semakin rendah nilai LDR menandakan semakin likuid bank tersebut (Ayem \& Wahyuni, 2017; Ramadaniar et al., 2013; Sulistiyorini, 2020). Berikut merupakan data kredit yang disalurkan oleh Bank Pembangunan Dearah di Indonesia, Dana Pihak Ketiga yang dihimpun dan nilai LDR pada Bank Pembangunan Daerah selama periode Januari 2019 sampai dengan Desember 2019 yang tersaji pada Tabel 4.

Tabel 4:

Rata-rata Jumlah Kredit, DPK dan LDR periode Januari sd Desember 2019

\begin{tabular}{cccccccc}
\hline \multirow{2}{*}{ Bulan } & $\begin{array}{c}\text { Kredit } \\
\text { (Miliar Rupiah) }\end{array}$ & $\begin{array}{c}\text { DPK } \\
\text { (Milyar Rupiah) }\end{array}$ & LDR & Bulan & $\begin{array}{c}\text { Kredit } \\
\text { (Miliar Rupiah) }\end{array}$ & $\begin{array}{c}\text { DPK } \\
\text { (Milyar Rupiah) }\end{array}$ & LDR \\
\hline Januari & 395.258 & 472.591 & $83,64 \%$ & Juli & 416.153 & 533.296 & $78,03 \%$ \\
Februari & 397.531 & 482.126 & $82,45 \%$ & Agustus & 423.533 & 531.085 & $79,75 \%$ \\
Maret & 403.658 & 496.723 & $81,26 \%$ & September & 434.527 & 549.899 & $79,02 \%$ \\
April & 405.269 & 532.321 & $77,44 \%$ & Oktober & 437.639 & 568.201 & $77,02 \%$ \\
Mei & 410.435 & 498.647 & $82,31 \%$ & November & 440.875 & 562.227 & $78,42 \%$ \\
Juni & 412.704 & 530.690 & $77,77 \%$ & Desember & 444.489 & 504.517 & $88,10 \%$ \\
\hline
\end{tabular}

Sumber: SPI OJK, 2019.

Sepanjang tahun 2019 LDR Bank Pembangunan Daerah di Indonesia mengalami fluktuasi, rata-rata LDR tahun 2019 ialah 80,43\% dan pada Desember 2019 LDR Bank Pembangunan Daerah dicatat sebesar $88,10 \%$.
Nilai LDR ini didukung oleh jumlah Dana Pihak Ketiga yang terkumpul pada Bank Pembangunan Daerah yang cenderung naik pada tahun 2019 dengan rata-rata Rp. 521.860 Milyar yang mencerminkan tingginya 
kepercayaan masyarakat untuk menyimpan dana dan bertransaksi di Bank Pembangunan Daerah, proporsi paling besar dari DPK yang terkumpul disalurkan dalam bentuk kredit dengan rata-rata Rp. 418.506 Miliar, sedangkan sisanya disalurkan dalam bentuk penempatan pada bank lain, penempatan pada Bank Indonesia, Surat Berharaga, dll (SPI OJK, 2019). Merujuk pada Peraturan Bank Indonesia BI No. 15/7/PBI/2013 yaitu nilai LDR standar perbankan ialah sebesar $78 \%$ sampai dengan 100\%. Rata-rata LDR Bank Pembangunan Daerah di Indonesia berada di pada range toleransi. LDR yang terdapat pada range toleransi yang ditetapkan Bank Indonesia ini menjadi gambaran atau menunjukkan bahwa Bank Pembangunan Daerah dalam melaksanakan kegiatan usahanya selalu memperoleh keuntungan (Ayem \& Wahyuni, 2017; I. G. A. P. Putri \& Suryantini, 2017). Maka dapat dikatakan LDR Bank Pembangunan Daerah di Indonesia sudah cukup baik atau dengan kata lain Bank Pembangunan Daerah di Indonesia termasuk dalam kategori likuid. Kenaikan dari jumlah Dana Pihak Ketiga yang dihimpun dari masyarakat dibarengi dengan kenaikan jumlah kredit yang disalurkan setiap bulannya, karena LDR berhubungan dengan bagaimana bank mengelola likuiditasnya yang menjadi salah satu permasalahan kompleks berkaitan dengan kegiatan usaha atau operasional bank hal ini disebabkan jumlah kredit yang disalurkan oleh bank merupakan dana yang dihimpun dari masyarakat dalam bentuk simpanan yang dapat diambil sewaktu-waktu oleh nasabah (Fiscal \& Lusiana, 2014; Octaviani, 2018; Paramita \& Dana, 2019). LDR ini ialah salah satu rasio yang menjadi indikator kesehatan bank dari sisi likuiditas, karena berkaitan dengan berjalan dengan baik atau tidak fungsi intermediasi bank yang bersangkutan (I. G. A. P. Putri \& Suryantini, 2017).

\section{PENUTUP}

Berdasarkan hasil penelitian yang telah dilaksanakan, diketahui bahwa Bank Pembangunan Daerah di Indonesia pada tahun 2019 memiliki rata-rata Capital Adequacy Ratio sebesar 21,7\% jauh diatas Capital Adequacy Ratio minimal yang ditetapkan oleh Bank Indonesia sebesar $8 \%$, serta memiliki rata-rata Return On Asset sebesar 2,16\% yang juga lebih besar dari minimal Return On Asset sebesar 1,5\%, selanjutnya untuk rata-rata Loan To
Deposit Ratio Bank Pembangunan Daerah sebesar $80,43 \%$ yang berada pada range standard LDR, sehingga dapat dikatakan Bank Pembangunan Daerah di Indonesia termasuk dalam ketrgori likuid. Maka berdasarkan hasil penelitian yang dilakukan dapat disimpulkan bahwa kinerja keuangan Bank Pembangunan Daerah di Indonesia selama periode Januari 2019 sampai dengan Desember 2019 adalah baik dan hal ini wajib di pertahankan untuk memberikan rasa aman dan nyaman serta kepercayaan dari masyarakat terhadap Bank Pembangunan Daerah terus meningkat.

\section{DAFTAR PUSTAKA}

\section{Jurnal}

Aprilianawati, D., Zahroh, Z. A., \& Nuzula, N. F. (2014). Analisis Pengawasan Kredit Usaha Rakyat (KUR) Dalam Meminimalisir Terjadinya Kredit Bermasalah ( Studi pada Bank Jatim Cabang Tulungagung Periode 2010-2013 ). Jurnal Administrasi Bisnis (JAB), 10(1), 1-9.

Assofia, H. (2019). Analisis Kinerja Keuangan Bank Aceh Setelah Konversi Periode 2016-2018 Berdasarkan Peraturan Otoritas Jasa Keuangan Nomor 8/POJK. 03/2014. At- Tawassuh, IV(1), 43-65.

Ayem, S., \& Wahyuni, S. (2017). Pengaruh Loan To Deposit Ratio, Capital Adequacy Ratio, Return on Asset dan Non Performing Loan Terhadap Return Saham. Jurnbal Akuntansi, 5(1), 71-87. https://doi.org/10.24964/ja.v5i1.258

Chandra, R. (2013). Analisis Pengaruh Capital Adequcy Ratio, Operational Efficiency, Non Performing Load dan Loan Tp Deposit Ratio terhadap Retun On Asset pada Bank BUMN di Indonesia. Jurnal Telaah Dan Rioset Akuntansi, 6(1), 3139.

Fiscal, Y., \& Lusiana, L. (2014). Pengaruh Capital Adequacy Ratio (CAR), Loan to Deposit Ratio (LDR), Biaya Operasional dan Pendapatan Operasional (BOPO) Terhadap Profitabilitas BPR. Jurnal Akuntansi Dan Keuangan, 5(2), 127-157.

M, M. S., Ali, M., \& Habbe, A. H. (2012). Pengaruh Rasio Kesehatan Bank Terhadap Kinerja Keuangan Bank Umum Syariah dan Bank Konvensional di Indonesia. Jurnal Analis, 1(1), 79-86.

Mamahit, E. Y., \& Sumiyarsih, S. (2018). Pengaruh CAR, NPL, dan ROA Terhadap 
Penyaluran Kredit Pada Bank Pemerintah. Future Jurnal Manajemen Dan Akuntansi, 6(September), 75-90.

Mandolang, A., Kumaat, R. J., \& Niode, A. N. O. (2017). Faktor-faktor yang mempengaruhi kredti umkm di sulawesi utara periode 2012.1-2015.4. Jurnal Berkala Ilmiah Efisiensi, 17(01), 34-43.

Octaviani, S. (2018). Pengaruh Non Performing Loan (NPL) dan Loan To Deposit Ratio (LDR) Terhadap Profitabilitas Pada Oerusahaan Perbankan yang Terdaftar di Bursa Efek Indonesia (BEI). Jurnal Akuntansi, 5(1), 64-73.

Paramita, P. K., \& Dana, I. M. (2019). Pengaruh Capital Adquacy Ratio, Non Performing Loan dan Loan To Deposit Ratio Terhadap Profitabilitas. E-Jurnal Manajemen, 8(2), 7633-7659.

Prawirasasra, K. P. (2018). Financial Technology in Indonesia: Disruptive or Collaborative? Reports on Economics and Finance, 4(2), 83-90.

Putri, I. G. A. P., \& Suryantini, N. P. S. (2017). Determinasi Loan To Deposit Ratio Pada Bank Campuran di Indonesia. E-Jurnal Manajemen Unud, 6(1), 204-234.

Putri, Y. M. W., \& Akmalia, A. (2016). Pengaruh CAR, NPL, ROA, dan LDR Terhadap Penyaluran Kredit pada Perbankan (Studi Pada Perusahaan Perbankan yang Listed di Bursa Efek Indonesia Periode 2011-2015). Jurnal Balance, XIII(2), 82-93.

Rahmani, N. A. B. (2017). Analisis Pengaruh Capital Adequacy Ratio ( CAR ) dan Financing to Deposit Ratio ( FDR ) terhadap Return On Asset ( ROA ) dan Return On Equity ( ROE ) Pada Perusahaan Bank Umum Syariah di Indonesia. Human Falah, 4(2), 299-316.

Ramadaniar, B., Topowijono, T., \& Husaini, A. (2013). Analisis Rasio Keuangan Perbankan Untuk Menilai Kinerja Keuangan Bank. Jurnal Administrasi Bisnis (JAB), 1(1), 49-58.

Rate, P. Van, Mangantar, M., \& Mamahit, R. M. F. (2016). Analisis Perbandingan Kinerja Keuangan Bank Milik Pemerintah Dengan Bank Milik Swasta Nasional Di Indonesia. Jurnal EMBA, 4(1), 295-305.

Septiyani, S., Mutmainah, I., \& Yulia, I. A. (2018). Analisis rasio Keuangan Untuk Menilai Kinerja Keuangan Pada Bank yang Terdaftar di BEI Periode 2017-2017,
XVII(2), 43-59.

Setiawan, A. (2017). Analisis Pengaruh Tingkat Kesehatan Bank Terhadap Return On Asset. Jurnal Analisa Akuntansi Dan Perpajakan, 1(September), 130-152.

Setiyono, W. P., \& Aini, M. N. (2014). Analisis Kinerja Keuangan Perbankan Dengan Menggunakan Metode Camel (Studi Kasus Pada PT. BPR Buduran Delta Purnama). BMP: Jurnal Bisnis, Manajemen Dan Perbankan, 1(2), 175196.

Sudarsono, H. (2017). Analisis Pengaruh Kinerja Keuangan terhadap Profitabilitas Bank Syariah di Indonesia Pendahuluan Return on Aset ( ROA ) atau profitabilitas merupakan rasio yang digunakan. Jurnal Economica: Jurnal Ekonomi Islam, 8(2), 175-203.

Sulistiyorini, E. (2020). Pengaruh DPK, NPL, CAR, dan LDR Terhadap Penyaluran Kredit (Studi Kasus Pada Bank Yang Terdaftar di Indeks LQ45 tahun 20142018). PETA, 5(1), 85-98.

Sumartono, S., \& Harianto, K. A. (2018). Kinerja Keuangan Perusahaan Asuransi Di Indonesia dan Faktor-faktor yang Mempengaruhinya. Future Jurnal Manajemen Dan Akuntansi, 6(September), $1-14$.

Wowiling, F. E. (2018). Analisis Pengaruh Kinerja Keuangan Bank Pembangunan Daerah (BPD) dan Bank Perkreditan Rakyat (BPR) Terhadap Pemberian Kredit Periode 2013-2016. Jurnal EMBA, 6(1), 81-90.

\section{Website}

Laporan Kinerja Industri Perbankan, https://www.ojk.go.id/id/kanal/perbankan /data-dan-statistik/laporan-profil-industriperbankan/Pages/-Laporan-ProfilIndustri-Perbankan---Triwulan-III2019.aspx, Diunduh tanggal 1 Maret 2020.

Peraturan Bank Indonesia BI No. 15/7/PBI/2013

https://www.bi.go.id/id/peraturan/perban kan/Pages/PBI 150713.aspx, Diunduh tanggal 1 Maret 2020.

Statistik Perbankan Indonesia, Otoritas Jasa Keuangan (SPI OJK). (2019).. https://www.ojk.go.id/id/kanal/perbankan /data-dan-statistik/statistik-perbankan- 
indonesia/Default.aspx, Diunduh tanggal 1 Maret 2020.

SE BI No.13/24/DPNP/2011

https://www.bi.go.id/id/peraturan/perban kan/Pages/SE\%20No.13_24_DPNP_201 $\underline{1 . \operatorname{aspx}}$ https://www.bi.go.id/id/peraturan/kodif ikasi/bank/Pages/1.3.3.2.\%20Penilaian\% 20Tingkat\%20Kesehatan\%20Bank.aspxdi unduh tanggal 1 Maret 2020. 